\title{
Study on the status quo and countermeasures of "marginalization" of Marxist ideology in colleges and universities
}

\author{
Yingying Xu \\ Keyi College of Zhejiang Sci-Tech University \\ E-mail:1448190224@qq.com
}

\begin{abstract}
This study involves a broad theoretical basis, based on China's mainstream ideology, with Marxist ideology throughout the text. Firstly explains the ideological theory, Marxist ideology in Chinese colleges and universities be marginal risk discusses and combs, the induction and summary of marxism in China's achievement at the same time, some problems also exist, timely find out the reasons, finally summarizes the present situation of the Marxist ideology in the marginalized, put forward the corresponding countermeasures, these countermeasures can insist on the guidance of the Marxist ideology position and leading role, and elevate the status of the mainstream ideology of colleges and universities.
\end{abstract}

Keywords: university; Marginalization of marxism; countermeasures

\section{Introduction}

In modern's world, cultural globalization as a blessing and a curse, it is to provide a new opportunity of popularization of marxism ideology at the same time, also brought challenges, colleges and universities ideology also produce new change, these changes for a certain impact in the mainstream ideology in our country, the Marxist ideology is facing the risk of marginalized, make college ideological problems are growing. Although colleges and universities provide a powerful guarantee for various ideological and cultural exchanges, it is of vital importance for us to adhere to the dominant position of marxism in the construction of mainstream ideology and strengthen the ideology of marxism in colleges and universities in the process of cultural diversification ${ }^{[1,2]}$.

\section{Marxist ideology}

The ideology of marxism is a scientific, objective, systematic, self-conscious, and practice-certified ideological system, a scientific theoretical system based on historical materialism that makes a comprehensive and in-depth study of socialism and communism. Marxist ideology is an ideological system opposed to bourgeois ideology, and it reflects the ideological system of the fundamental interests of the proletariat and the broad masses of the people. The ideology of the bourgeoisie is a false ideology system that serves the stage of assets. In the long-term revolutionary practice, Marx and Engels believed that the ideology in the asset stage was a kind of false ideology and should be criticized, so they carried out a series of revolutionary transformation and creation, and established the Marxist ideology ${ }^{[3]}$. The completion of German ideology in 1846 marked the birth of Marxist ideological theory, which made the socialist ideological system more scientific, objective, and systematic. The period from the 1870s to the 1890s was the systematization of Marxist philosophy. Marx and Engels regarded ideology as "the superstructure of ideas", which was a reflection of specific social forms. As Engels said, people consciously or unconsciously absorb their moral concepts from the economic relations of their class. They not only objectively analyzed the economic origin of ideology but also analyzed the ideological origin.

Copyright $@ 2020$ Yingying Xu

doi: $10.18282 /$ le.v9i5.1206

This is an open-access article distributed under the terms of the Creative Commons Attribution Non-Commercial License

(http://creativecommons.org/licenses/by-nc/4.0/), which permits unrestricted non-commercial use, distribution, and reproduction in any medium, provided the original work is properly cited. 


\section{The risk of the marginalization of Marxist ideology in Chinese universities}

Colleges and universities are at the forefront of ideological work, shouldering the important task of studying, studying and propagating marxism, cultivating and carrying forward socialist core values, and providing talent guarantee and intellectual support for the realization of the Chinese Dream of the great rejuvenation of the Chinese nation. They have become an important front for the spread of Marxist. In recent years, however, some people constantly reflect the serious "westernization" of higher education. The emergence of serious ideological problems in institutions of higher learning means that in the field of social science education, such as economics and law, Marxist theory has been seriously marginalized, while the western bourgeois theory has been strengthened and mainstreamed. For example, we uncritically introduced the western social science curriculum; We have introduced the original textbooks that reflect the ideology and values of the western bourgeoisie. Some of the 985 and 211 universities, which are among the leading ones in China, have also introduced foreign deans from economics schools that have not been influenced by marxism. Under the leadership of the "foreign" dean, the faculty of these colleges have become "foreign" doctors, and the academic evaluation system of these colleges has also been westernized ${ }^{[4]}$.

The central government has stressed that to do a good job in the publicity and ideological work of colleges and universities concerns the party's leadership over colleges and universities, the comprehensive implementation of the party's educational policy, and the successor to the cause of socialism with Chinese characteristics. The central government's emphasis on the propaganda and ideological work in colleges and universities is of great importance and far-reaching significance for consolidating the guiding position of Marxism in the ideological field and consolidating the common ideological basis for the unity and struggle of the whole party and the whole nation. The central government emphasizes to do a good job in the propaganda and ideological work of colleges and universities and to strengthen the construction of the ideological position of colleges and universities. The minister of education, the leaders of education departments in provinces and cities, and the party committees of many colleges and universities also came out one after another to show their determination to do a good job in the ideological work of colleges and universities ${ }^{[5]}$.

\section{Countermeasures of Chinese colleges and universities to maintain the dominant position of Marxist ideology}

Socialist society as the first stage of communism, is in the contradiction movement of capitalist society, in the development of capitalism to its basic contradictions intensified period time, in the decline of the bourgeoisie and the proletariat power contrast, growing because of the proletariat against the bourgeoisie and the birth of the new society. It is undeniable that in the late 20th century, due to the changes in the international situation, the historical process of transition from capitalism to socialism appeared some complicated situations. The failure of the socialist cause in the countries of the Soviet Union and Eastern Europe by no means means that the development trend of human society has changed because the basic contradiction of capitalism remains and is still intensifying. As far as the general trend of human history is concerned, the demise of the bourgeoisie and the victory of the proletariat are still inevitable. Although the building of socialism with Chinese characteristics still has to face the encirclement of international imperialism and the unfavorable situation of "the west is strong and the west is weak" in the international communist movement, the final victory still belongs to us. We must face unprecedented difficulties and challenges and work tirelessly to overcome them. To overcome these difficulties and challenges in building socialism with Chinese characteristics, we must first have strong and unshakable marxism and the ideology of socialism with Chinese characteristics. Institutions of higher learning are at the forefront of ideological work, shouldering the important task of learning, studying and propagating marxism, cultivating and carrying forward the core socialist values, and providing talent guarantee and intellectual support for the realization of the Chinese dream of great national rejuvenation ${ }^{[6]}$.

\subsection{As the ideological front of socialism with Chinese characteristics, colleges and universities must adhere to the correct direction of running schools}

To solve the problem of ideology in colleges and universities, we must first solve the problem of what kind of university we want. In the spring of 2014, on the occasion of the May 4th youth day, comrade Xi Jinping visited Peking 
University. While affirming PUK's goal of becoming a world-class university by 2018, comrade Xi Jinping also called on PKU to build a university based on the land of China, instead of making PKU "the second Harvard and Cambridge University", and to make PKU "the first PKU". When xi Jinping called Peking University "rooted in the land of China", he stressed that China's higher education should not only serve the construction of a country with 9.6 million square kilometers of land as its boundary but also serve the construction of socialism with Chinese characteristics that we are carrying out on the land of China. The implied meaning of "the first Peking University" is by no means that we will not compete with the world's top universities ${ }^{[7]}$. It is by no means that we are satisfied with "the first in China" from a narrow perspective. Socialism with Chinese characteristics is an unprecedented cause and the noblest cause in human history. Peking University, as a part of this great cause and in service of it, is the first in China and, of course, in the world. Therefore, we can temporarily not compete with the world's top Harvard University and Cambridge university ranking, but to build a solid socialist university, such Peking University must be ahead of Harvard University and Cambridge University, is China's first Beijing university ${ }^{[8]}$.

Marxist ideology is the essence and soul of socialist ideology. Only by maintaining the dominant position of Marxist ideology can we consolidate the spiritual pillar and ideological foundation of socialism. However, the maintenance of the dominant position of Marxist ideology and the play of its dominant role is not automatically realized. Cultural globalization has brought severe challenges to the security of Marxist ideology in China. Without an effective response, Marxist ideology risks being marginalized. How to adapt to the changes of The Times and make marxism more popular is of great practical and theoretical significance to ensure the status of marxism as the mainstream ideology.

\subsection{Constantly consolidating the class and economic basis of Marxist ideology.}

As Marx said: "the consciousness of all forms and product is not can be eliminated by spirit of criticism can melt them in a 'self-consciousness or ghost in the blame, blame that want to eliminate and so on and it is only through the actual overthrow all this idealism theory by the reality of social relations to them,Elimination "to consolidate the leading position of marxism in the ideological field will from strengthen its class foundation and economic foundation, to treat both specifically to enhance the marxist maintenance or represented by the class power is mainly the workers and peasants and know only molecules as the main body of the strength of the proletariat to enhance the strength of the proletariat is to strengthen their possession of material production and contribution to the social material wealth and spirit on the basis of the established in the construction of a firm political knowledge, clear mind discipline a rigorous style of marxism theory propaganda team in any $\mathrm{so}^{[9]}$.

\subsection{Adhere to the continuous innovation of Marxist ideology}

In the face of the growing non-mainstream ideology accompanying the birth and development of the new social class, the mainstream ideology either tries its best to fight against it, helps the class standing behind it and the state apparatus it owns, restricts the attack on the new force and its ideological result, or wins the victory ${ }^{[10]}$.

\section{Conclusion}

Consolidate the original position, or lose and be marginalized from the dominant position; Or mainstream ideology actively absorb reasonable rich these emerging ideological and improve the original system and the content and form to reflect the new social class interests and requirements of the ideological system is essentially the process of innovation process since "can force people to give up idealism nor forced people to believe in marxism", only rely on the truth of marxism ideology itself charm to conquer the heart make marxism ideology "with the development of human social practice and the development of science and development. Innovation is the fundamental requirement of Marxist innovation of marxism in addition to the meaning of marxism with the change of social-historical environment, the connotation of ideology should constantly make breakthroughs to reflect the social stratum and social structure that cannot change. Besides the trend of globalization and informatization, the propaganda of Marxist ideology also needs innovation. To realize the continuous innovation of Marxist ideology and to adhere to and develop in the process of development is not only the need for the development of The Times but also the need for the eternal vitality of Marxist ideology. 


\section{Reference}

1. Selected Works of Marx and Engels: Volume 1 [M]. Beijing: People's Publishing House, 1995.

2. Complete Works of Marx and Engels: Volume 3 [M]. Beijing: People's Publishing House,1969.

3. Liu Mingjun, Zheng Chunlai. Multi-cultural Conflict and construction of Mainstream Ideology [M]. Beijing: China Social Sciences Press,2008:3

4. wu zhiyan. How to understand the ideology of marxism [J]. Journal of chongqing university of posts and telecommunications (social science edition),2011,23(01):13-16+32.

5. Lin Baotang. Research on Countermeasures to Promote the Popularization of Marxism in Universities [J]. Neijiang Science and Technology, 2010, 31(4):50-50.

6. wang shufang. Realistic reflections on marxist ideological education in colleges and universities [J]. Research on ideological and political education,2011,27(03):52-55.

7. He Lingling, Yang Yi. Exploration and Reflection: Marxist ideology is facing the crisis of being "marginalized" [J]. Factualism,2006(07):11-14.

8. Fan Shucheng, Li Yuexi, Zhao Zhongxiang. Analysis of the Current Situation of Marxist Ideology and Research on construction Countermeasures [J]. Journal of Hebei Normal University (Philosophy and Social Science Edition),2006(04):5-10.

9. Zhu Zhaozhong. On the Construction of Socialist Ideology in China [M]. Shanghai: Shanghai People's Publishing House, 2003.

10. Francis Fukuyama. The End of History [M]. Beijing: Faraway Press,1989. 